\section{Evaluation of Peat Blended with Pine Wood Components for Effects on Substrate Physical Properties, Nitrogen Immobilization, and Growth of Petunia (Petunia $\times$ hybrida Vilm.-Andr.)}

\author{
Ryan W. Dickson and Kalyn M. Helms \\ Department of Horticulture, University of Arkansas, Fayetteville, AR 72701 \\ Brian E. Jackson \\ Department of Horticultural Science, North Carolina State University, \\ Raleigh, NC 27695
}

Leala M. Machesney

Department of Horticulture, University of Arkansas, Fayetteville, AR 72701

Jung Ae Lee

Department of Agricultural Statistics, University of Arkansas, Fayetteville, AR 72701

Additional index words. bark, coir, floriculture, perlite, pine wood fiber, pine tree substrate

Abstract. The first objective was to evaluate wood components for differences in nitrogen (N) immobilization and effects on substrate physical properties. The second objective was to evaluate peat substrates amended with pine wood components for effects on plant growth, shoot tissue $\mathbf{N}$, and fertigation practices during production. Substrates consisted of a coarse sphagnum peat blended with four types of processed pine wood at rates of $15 \%, 30 \%, 45 \%$, and $60 \%$ (by volume). For comparison, peat was also blended with an aged pine bark, perlite, and coconut coir. Nitrogen immobilization was measured for individual components, except perlite. Individual components and blended substrates were evaluated for particle size distribution, total air porosity, container capacity, and dry bulk density. In a greenhouse experiment, petunia (Petunia $\times$ hybrida Vilm.-Andr.) were grown in hanging basket containers with each substrate blend as well as $\mathbf{1 0 0 \%}$ peat, which served as a nonblended control substrate, and fertilized at each irrigation with $200 \mathrm{mg} \cdot \mathrm{L}^{-1} \mathrm{~N}$. Blended component and blend percent interacted in effects on all measured substrate physical properties; however, physical properties of all substrate blends were considered adequate for horticultural purposes. In the laboratory, pine bark immobilized $9 \%$ of total $\mathrm{N}$ supplied, whereas the remaining pine wood components immobilized $<5 \%$ of total $N$. In the greenhouse experiment, blend component influenced shoot growth and flowering, which were greatest for petunia grown in $\mathbf{1 0 0 \%}$ peat. Increasing the blend percent of all components decreased shoot growth and flowering with all blended components. Blended substrates had minimal effects on number of fertigation events, and substrate treatments differed by a maximum of three fertigation events per container over a 56-d period. This study illustrates the challenges of measuring $\mathrm{N}$ immobilization because results from the laboratory were not consistent with plant performance in the greenhouse. Increasing blends of each substrate (including perlite) were also observed to interact with fertigation practices and therefore applied $\mathrm{N}$, tissue $\mathrm{N}$, shoot dry weight, and total $\mathrm{N}$ uptake. As a practical conclusion from this study, peat incorporated with $60 \%$ wood fiber increased the risk of reduced plant growth and $\mathrm{N}$ uptake, but this risk was lower as the blend percentage decreased. In addition, other analytical methods to test $\mathrm{N}$ immobilization, such as microbial respiration, should be further explored.

Pine wood components are increasingly being used in soilless substrates to produce floriculture crops in the United States, particularly as a substitute for peat and perlite (Drotleff, 2018; Harris et al., 2020). Sphagnum peatmoss is the major component of soilless substrates for bedding plants and is often blended with perlite to improve substrate air porosity and drainage properties (Argo and Fisher, 2002; Nelson, 2011). However, concerns regarding the sustainability of harvesting peat as well as its future availability plant uptake when used in soilless substrates (Blok et al., 2008; Handreck, 1992a, 1992b, 1993; Jackson et al., 2009; Maher et al., 2008; Prasad, 1996a). Nitrogen immobilization results from microbial decomposition of organic matter, particularly when the carbon-to-nitrogen $(\mathrm{C}: \mathrm{N})$ ratio of the organic material exceeds 30:1 (Bunt, 1988; Nelson, 2011). Aged barks, sawdust, hammer-milled pine tree materials, and other wood components used in container production can have $\mathrm{C}: \mathrm{N}$ ratios of $300: 1$ or greater (Maher et al., 2008; Nelson, 2011; Prasad, 1996b) and potentially reduce available $\mathrm{N}$ from the applied fertilizer. Immobilization also occurs with nonwood organic components with relatively high $\mathrm{C}: \mathrm{N}$ ratios, such as coconut coir fiber (Maher et al., 2008; Prasad, 1996a). Organic components with relatively low C:N ratios $(\approx 30: 1$ or less), such as peatmosses and organic composts, tend to have minimal effects on $\mathrm{N}$ immobilization, and may mineralize $\mathrm{N}$ (release additional N) over time (Bunt, 1988; Raviv, 2005). Additional factors influencing microbial activity and availability of root zone $\mathrm{N}$ include temperature, moisture level, $\mathrm{pH}$, root zone oxygen, $\mathrm{N}$ form, carbon source, and molecular structure (Geisseler et al., 2010; Handreck, 1993; Jackson et al., 2009; Schulten and Schnitzer, 1998).

Previous research has shown that blending peat substrates with wood components can increase N immobilization (Gruda et al., 2000; Handreck, 1993; Harris et al., 2020; Jackson et al., 2008; Prasad, 1996a; Wright et al., 2008 ), especially at $40 \%$ by volume or greater. In addition to $\mathrm{N}$ immobilization, certain wood materials can leach toxic compounds that inhibit plant growth into the root zone (Bugbee and Heins, 2018; Bunt, 1988; Ortega et al., 1996), particularly if the wood has not been sufficiently aged or processed. Wood components typically retain less water by volume compared with sphagnum peat (Argo, 1998; Bugbee and Heins, 2018; Maher et al., 2008), and greater proportions of wood may reduce water-holding capacity and require more frequent irrigation during crop production.

There is a need to understand the potential of major wood components used commercially in the U.S. industry to influence substrate physical properties, $\mathrm{N}$ immobilization, and fertigation practices (i.e., combined fertilization and irrigation). Comparing major sources of wood fiber vs. more traditional substrate materials, such as perlite, coir, and aged pine bark, may also highlight some of the potential advantages and disadvantages of these materials.

The first objective was to evaluate the physical properties and $\mathrm{N}$ immobilization rate for four pine wood components. The second objective was to evaluate peat-based substrates blended with four pine wood components for effects on plant growth, shoot tissue $\mathrm{N}$, and fertigation practices. We hypothesized that peat containing pine wood components would increase $\mathrm{N}$ immobilization rates, reduce $\mathrm{N}$ uptake, and decrease plant growth. We also hypothesized that peat containing pine wood components would decrease 
substrate water-holding capacity and increase irrigation frequency.

\section{Materials and Methods}

Blending of research substrates. A coarse Latvian sphagnum peat (Pindstrup Peat Moss Professional-Grower Grade; Pindstrup, Ryomgaard, Denmark) containing long fibers and little dust (von Post scale 2-3; Puustjarvi and Robertson, 1975) was blended with ForestGold a disc-refined wood fiber made from Scots pine (Pinus sylvestris) [FG (Pindstrup)], GreenFibre, an extruded $P$. sylvestris fiber [GF (KlasmannDeilmann, Geeste, Germany)], HydraFiber, a disc-refined loblolly pine $(P$. taeda) fiber [HF (Profile Products, LLC, Buffalo Grove, IL)], a hammer-milled loblolly pine tree substrate [PTS (North Carolina State University Horticultural Substrates Laboratory, Raleigh, NC)], 0.95-cm aged pine bark (SunGro Horticulture, Agawam, MA), coconut coir (MillenniumSoils Farm, St. Catherines, Ontario, Canada), and coarse grade perlite (Supreme Perlite, Portland, $\mathrm{OR})$. The coconut coir was leached with deionized water to remove soluble salts before substrate formulation.

The research substrates consisted of the peat blended with each of the seven components at four blend percentages $(15 \%, 30 \%$, $45 \%$, and $60 \%$ by volume). All substrates were hand-blended. The fibers for FG and HF components along with the $100 \%$ peat substrate were highly interwoven and tended to form clumps, and separation by hand was necessary to minimize aggregate clumps and maximize the distribution of fibers throughout the blend. In commercial practice, HF materials are often blended with peat using mechanical equipment (Drotleff, 2018)

Substrate physical properties and nitrogen immobilization. Three replicate samples for each blended substrate treatment and raw substrate component were evaluated for dry bulk density, percent water space at container capacity (CC), percent air space (AS), and percent total pore space (TP). Measurements were collected using the NCSU Porometer Method described by Fonteno et al. (1995). Particle size distribution was also measured and consisted of passing 150-g oven-dried samples through five U.S. Standard sieves (ranging from 0.1- to 6.3-mm-diameter mesh sizes) plus a bottom pan. Sieves and pan were shaken for 10 min using an RX-29 Ro-

Received for publication 4 Aug. 2021. Accepted for publication 25 Oct. 2021.

Published online 17 January 2022.

We thank the Arkansas Division of Agriculture, Arkansas Agricultural Experiment Station, the U.S. Department of Agriculture National Institute of Food and Agriculture projects \#1022864 and \#1019001, and Pindstrup LLC, for providing support and donations of research supplies. We also thank Joshua Tebow for data collection at the University of Arkansas.

R.W.D. is the corresponding author. E-mail: ryand@uark.edu.

This is an open access article distributed under the CC BY-NC-ND license (https://creativecommons. org/licenses/by-nc-nd/4.0/).
Tap sieve shaker (278 oscillations per min, 150 taps per min; W.S. Tyler, Mentor, $\mathrm{OH}$ ), and the particle fractions retained on each sieve and pan were weighed and evaluated as a percentage of the total sample.

Nitrogen immobilization was measured for each component, except for perlite, using a modified procedure for testing $\mathrm{N}$ immobilization/mineralization in soilless substrates from the Association of German Agricultural Analytic and Research Institute (VDLUFA, 2007). Samples of each component ( $250 \mathrm{~mL} / \mathrm{sample})$ were placed in $500-\mathrm{mL}$ plastic vessels, were lightly compacted, and had the moisture content adjusted to $80 \%$ of CC. Five milliliters of reagent-grade ammonium nitrate $\left(\mathrm{NH}_{4} \mathrm{NO}_{3}\right)$ solution mixed at $50 \mathrm{~g} \cdot \mathrm{L}^{-1} \mathrm{~N}$ in deionized water was incorporated into each sample adding $250 \mathrm{mg} \mathrm{N}$ per sample (1000 mg N per liter of sample), which served as part of the initial adjustment of moisture content, where the remaining moisture adjustment used deionized water. Vessels were sealed with a permeable film and incubated at $25^{\circ} \mathrm{C}$ for $21 \mathrm{~d}$. Sample moisture content was checked gravimetrically every 2 to $3 \mathrm{~d}$ during incubation and maintained at $80 \%$ of maximum CC by adding back deionized water as needed. For each component type, $\mathrm{N}$ was extracted from three replicate vessels at 0 and $21 \mathrm{~d}$ by flushing each sample with $600 \mathrm{~mL}$ of the calcium chloride/chelate extraction solution described by Sonneveld and Voogt (2009), and by filtering the leachate under vacuum suction. Ammonium $\left(\mathrm{NH}_{4}-\mathrm{N}\right)$ and nitrate $\left(\mathrm{NO}_{3}-\mathrm{N}\right) \mathrm{N}$ were analyzed in the filtered solution using a persulfate digestion method (Purcell and King, 1996). Potential for $\mathrm{N}$ immobilization was evaluated as the difference in extracted $\mathrm{N}$ between 0 and $21 \mathrm{~d}$ for each component, measured by subtracting the $\mathrm{N}$ extracted from each replicate at $21 \mathrm{~d}$ from the average extracted $\mathrm{N}$ at $0 \mathrm{~d}$.

Greenhouse experiment. In a seven component $\times$ four blend percent factorial experiment, the same substrate treatments previously described for physical properties and $\mathrm{N}$ immobilization testing were evaluated for effects on plant growth, shoot tissue $\mathrm{N}$, and fertigation practices with petunia 'Supertunia Vista Bubblegum' (Petunia $\times$ hybrida Vilm.-Andr.) grown in hanging basket containers. In addition to the blended substrate treatments, petunia were also grown in $100 \%$ peat, which served as a nonblended reference substrate. There were four replicates for each blended substrate treatment, where each replicate was one containerized plant, arranged using a randomized complete block design, as well as eight replicates for the $100 \%$ peat reference substrate. Plants were grown on benches in a glass greenhouse at the University of Arkansas (Fayetteville, AR). Daily light integral (DLI) and average daily air temperature (ADT) were measured using a Watchdog WeatherTracker Plant Growth Station (Spectrum Technologies, Aurora, IL), and DLI and ADT were (mean \pm sd) $24.8 \pm 10.4$ $\mathrm{mol} \cdot \mathrm{m}^{-2} \cdot \mathrm{d}^{-1}$ of photosynthetically active radiation and $19.8 \pm 1.6^{\circ} \mathrm{C}$, respectively.

Dolomitic limestone was preincorporated into the commercial-grade sphagnum peat, and no addition limestone was incorporated after blending. Substrate treatments were incorporated with a preplant nutrient charge from a commercial $\quad 17.0 \mathrm{~N}-2.2 \mathrm{P}-14.1 \mathrm{~K}-4.0 \mathrm{Ca}-1.0$ $\mathrm{Mg}$ water-soluble fertilizer (GreenCare Fertilizers, Kakankee, IL) at $10.6 \mathrm{~g} \cdot \mathrm{m}^{-3} \mathrm{~N}$ as well as a wetting agent (PsiMatric; Aquatrols, Paulsboro, NJ) at $150 \mathrm{~mL} \cdot \mathrm{m}^{-3}$. Substrate $\mathrm{pH}$ and electrical conductivity (EC) were measured for each replicate following the first fertigation event at transplant using a nondestructive PourThru method described by Wright (1986) and Orion Dual Star benchtop meter (Thermo Fisher Scientific, Waltham, MA). Substrate $\mathrm{pH}$ was (mean $\pm \mathrm{sd}$ ) $5.9 \pm 0.2$ and $\mathrm{EC}$ was $2.1 \pm$ $0.1 \mathrm{mS} \cdot \mathrm{cm}^{-1}$ across all treatment replicates.

Vegetatively propagated liners of petunia 'Supertunia Vista Bubblegum' (Petunia $\times$ hybrida Vilm.-Andr.) in 128-cell trays were potted into $25.4-\mathrm{cm}$ diameter plastic hanging basket containers (Poppelmann Plastics US LLC, Claremont, NC) at one plant per container. Containers were filled to a uniform volume, and substrate compaction level was adjusted to ensure container replicates of the same treatment were filled with a consistent amount of substrate. Each container was irrigated to $\mathrm{CC}$ with fertilizer solution (i.e., fertigated) at transplant and throughout the experiment using a commercial $17.0 \mathrm{~N}-2.2 \mathrm{P}$ $14.1 \mathrm{~K}-4.0 \mathrm{Ca}-1.0 \mathrm{Mg}$ water-soluble fertilizer (GreenCare Fertilizers, Kakankee, IL) at 200 $\mathrm{mg} \cdot \mathrm{L}^{-1} \mathrm{~N}$ mixed in tap water with $<60 \mathrm{mg} \cdot \mathrm{L}^{-1}$ bicarbonate alkalinity and EC of $0.3 \mathrm{mS} \cdot \mathrm{cm}^{-1}$

Each replicate container was individually hand-fertigated and brought back to $\mathrm{CC}$ once substrate moisture (container weight) decreased to $50 \%$ of the maximum CC. Moisture content was determined by weighing each container twice daily between 0900 to $1100 \mathrm{HR}$ and 1500 to $1700 \mathrm{HR}$. Correlations between container weight and moisture content were determined using gravimetric techniques for each blended substrate treatment and adjusted every $7 \mathrm{~d}$ to account for increasing plant growth. Fertilizer solution was applied by hand directly to the substrate surface and underneath the plant canopy to avoid wetting the foliage. Total volume of fertilizer solution applied and retained per replicate was measured by the difference in total container weight before and after each irrigation event, allowing $15 \mathrm{~min}$ for drainage to stop following irrigation. The total number of fertigation events per replicate was also recorded as a measure of fertigation frequency.

At $28 \mathrm{~d}$ after transplant, shoots that started to extend past the container rim $(25.4-\mathrm{cm}$ diameter) were pruned back to the rim and at a $10-\mathrm{cm}$ height to promote a uniform new flush of growth. At the same time, $40 \mathrm{mg} \cdot \mathrm{L}^{-1}$ paclobutrazol (Bonzi; Syngenta Crop Protection, Greensboro, NC) was foliar-applied at $\approx 200$ $\mathrm{mL} \cdot \mathrm{m}^{-2}$ of bench space to promote a compact growth habit. Pruning and chemical plant growth regulator applications were designed to simulate commercial practices for producing high-quality petunia in hanging baskets.

Final data collection occurred $56 \mathrm{~d}$ after transplant. Substrate $\mathrm{pH}$ and EC were measured in leachate collected from each replicate container using the nondestructive PourThru method 
described by Wright (1986) using the same benchtop $\mathrm{pH}$ and $\mathrm{EC}$ meter described earlier.

Leaf SPAD chlorophyll content was measured nondestructively for each replicate (SPAD 502 Plus Index Meter; Konica Minolta, Tokyo, Japan). Each leaf SPAD value consisted of the average of five measurements taken on randomly selected leaves per plant. Flower number was measured for each replicate as the number of open flowers, and plant dimensions were measured as canopy height from the substrate surface and canopy width at the widest point.

Plant growth was measured as shoot dry weight per replicate by destructively harvesting shoot tissue just above the substrate surface and oven-drying at $70^{\circ} \mathrm{C}$ for $36 \mathrm{~h}$. Dried whole-shoot tissue samples were ground and analyzed for total $\mathrm{N}$ concentration using a persulfate digestion and colorimetric method (University of Arkansas Plant Diagnostics Laboratory, Fayetteville, AR).

Statistical analysis. Analysis of variance (ANOVA) with PROC GLIMMIX in SAS 9.4 (SAS Institute, Cary, NC) was used to evaluate blended substrate effects on physical properties, and to evaluate individual substrate component effects on particle size distribution and $\mathrm{N}$ immobilization. For the greenhouse experiment, PROC GLIMMIX was also used to evaluate substrate effects on substrate $\mathrm{pH}$ and $\mathrm{EC}$, leaf SPAD chlorophyll content, flower number, canopy height and width, shoot dry weight, shoot $\mathrm{N}$ concentration, applied fertigation volume and frequency. Petunia in $100 \%$ peat (nonblended reference substrate) were grown alongside the plants in the blended substrate treatments and included in the experimental blocks but were not part of the factorial design and randomization and therefore not included in the ANOVA. However, data and $\pm 95 \%$ confidence limits from the $100 \%$ peat are presented and discussed in the results section as a comparison with the blended substrate treatments. Means separation of the blended substrate treatments used Tukey's honestly significant difference at $\alpha=0.05$.

\section{Results and Discussion}

Physical properties of individual substrate components. Substrate components differed in distribution of particle sizes, as shown in Table 1. Perlite and bark had the highest percentages of particles in the coarse-sized fraction $(>2 \mathrm{~mm})$ at $70.5 \%$ and $52.5 \%$, respectively (Table 1). Peat and FG also had relatively high percentages of coarse-sized particles at $49.0 \%$ and $43.7 \%$, respectively, partially because these components contained aggregated clumps of fibrous material that did not fragment during sieving. Most particles were in the medium-sized fraction $(0.3$ to 2 $\mathrm{mm})$ for coir $(66.1 \%)$, GF $(72.2 \%)$, HF (51.0\%), and PTS $(82.7 \%)$. HF also contained fibrous clumps that were smaller compared with the peat and FG. The highest percentages of fine-sized particles occurred with the fibrous substrate components including peat $(14.8 \%)$, FG (23.6\%), GF (20.6\%), and HF (35.1\%).
Table 1. Particle size distribution of individual substrate components. Data represent least-square means of three replicates. Means separation used Tukey's honestly significant difference at $\alpha=0.05$.

\begin{tabular}{|c|c|c|c|c|c|c|}
\hline \multirow[b]{3}{*}{ Component } & \multicolumn{6}{|c|}{ Particle size distribution ( $\%$ of dry wt) } \\
\hline & \multicolumn{2}{|c|}{ Coarse } & \multicolumn{2}{|c|}{ Medium } & \multicolumn{2}{|c|}{ Fine } \\
\hline & $>6.3 \mathrm{~mm}$ & $2.0-6.3 \mathrm{~mm}$ & $0.5-2.0 \mathrm{~mm}$ & $0.3-0.5 \mathrm{~mm}$ & $0.1-0.3 \mathrm{~mm}$ & $<0.1 \mathrm{~mm}$ \\
\hline Peat & $21.4 \mathrm{a}$ & $27.6 \mathrm{c}$ & $23.4 \mathrm{c}$ & $12.9 \mathrm{c}$ & $7.3 \mathrm{bc}$ & $7.5 \mathrm{c}$ \\
\hline Perlite & $4.7 \mathrm{~b}$ & $65.8 \mathrm{a}$ & $14.9 \mathrm{c}$ & $1.9 \mathrm{~d}$ & $1.0 \mathrm{e}$ & $6.8 \mathrm{c}$ \\
\hline Coir & $0.0 \mathrm{~b}$ & $2.6 \mathrm{e}$ & $47.8 \mathrm{~b}$ & $18.3 \mathrm{~b}$ & $4.8 \mathrm{~cd}$ & $0.6 \mathrm{~d}$ \\
\hline Bark & $4.2 \mathrm{~b}$ & $48.3 \mathrm{~b}$ & $40.8 \mathrm{~b}$ & $3.9 \mathrm{~d}$ & $1.7 \mathrm{de}$ & $0.6 \mathrm{~d}$ \\
\hline FG & $14.5 \mathrm{a}$ & $29.2 \mathrm{c}$ & $21.2 \mathrm{c}$ & $11.4 \mathrm{c}$ & $10.0 \mathrm{ab}$ & $13.6 \mathrm{~b}$ \\
\hline GF & $0.0 \mathrm{~b}$ & $7.2 \mathrm{de}$ & $47.1 \mathrm{~b}$ & $25.1 \mathrm{a}$ & $12.3 \mathrm{a}$ & $8.3 \mathrm{c}$ \\
\hline $\mathrm{HF}$ & $3.7 \mathrm{~b}$ & $10.3 \mathrm{~d}$ & $36.5 \mathrm{bc}$ & $14.5 \mathrm{bc}$ & $13.3 \mathrm{a}$ & $21.8 \mathrm{a}$ \\
\hline PTS & $\begin{array}{l}0.0 \mathrm{~b} \\
* * *\end{array}$ & $\begin{array}{c}8.8 \mathrm{de} \\
* * *\end{array}$ & $\begin{array}{c}68.6 \mathrm{a} \\
* * *\end{array}$ & $\begin{array}{c}14.1 \mathrm{c} \\
* * *\end{array}$ & $\begin{array}{l}5.0 \mathrm{~cd} \\
* * *\end{array}$ & $\begin{array}{l}2.3 \mathrm{~d} \\
* * *\end{array}$ \\
\hline
\end{tabular}

$\overline{\mathrm{FG}}=$ ForestGold; GF $=$ GreenFibre; $\mathrm{HF}=$ HydraFiber; PTS $=$ pine tree substrate. *** Significant at $P \leq 0.0001$.
The higher percentage of fine particles for these materials may have partially resulted from delicate fibers being damaged during sieving (Bartley, 2019). The coir used in this study contained mostly pith and was not as fibrous as the peat, FG, GF, and HF components (Fig. 1).

Total porosity was greatest for coir, FG, $\mathrm{GF}$, and $\mathrm{HF}$ at $>90 \%$ by volume (Table 2 ), but all components had relatively high $\mathrm{TP}$ at $>70 \%$. Air space was similar across FG, GF, and $\mathrm{HF}$, averaging $33.2 \%$ across components (Table 2), which was greater compared with peat and coir but lower than perlite. Container capacity was also similar across FG, GF, and $\mathrm{HF}$, averaging $60.7 \%$, which was comparable to PTS and peat, greater than perlite and bark, and lower than coir (Table 2). FG and HF had dry bulk densities of 50 and 60 $\mathrm{g} \cdot \mathrm{L}^{-1}$, respectively, and were overall more similar to coir whereas GF had a dry bulk density of $153.3 \mathrm{~g} \cdot \mathrm{L}^{-1}$ and was more similar to PTS and perlite. FG, GF, and HF components had dry bulk densities similar to peat (Table 2). Aged pine bark had the greatest dry bulk density of all components (Table 2).

Physical properties for blended substrates. The blended component and blend percent interacted in effect on TP, CC, and AS (Fig. 2). As the blend percent increased, the TP increased for peat blended with HF, GF, coir, and PTS but decreased with perlite and bark and remained stable for FG (Fig. 2A). Total porosity was most similar across substrates when components were blended at $15 \%$, and differences in TP became greater as the blend percent increased to $45 \%$ and $60 \%$ (Fig. 2A). Yeager et al. (2007) recommended total porosity range from $50 \%$ to $85 \%$ for substrates used in nursery production, but there are currently no established standards or guidelines for greenhouse substrates. Total porosity can exceed $85 \%$ for substrates used in greenhouse

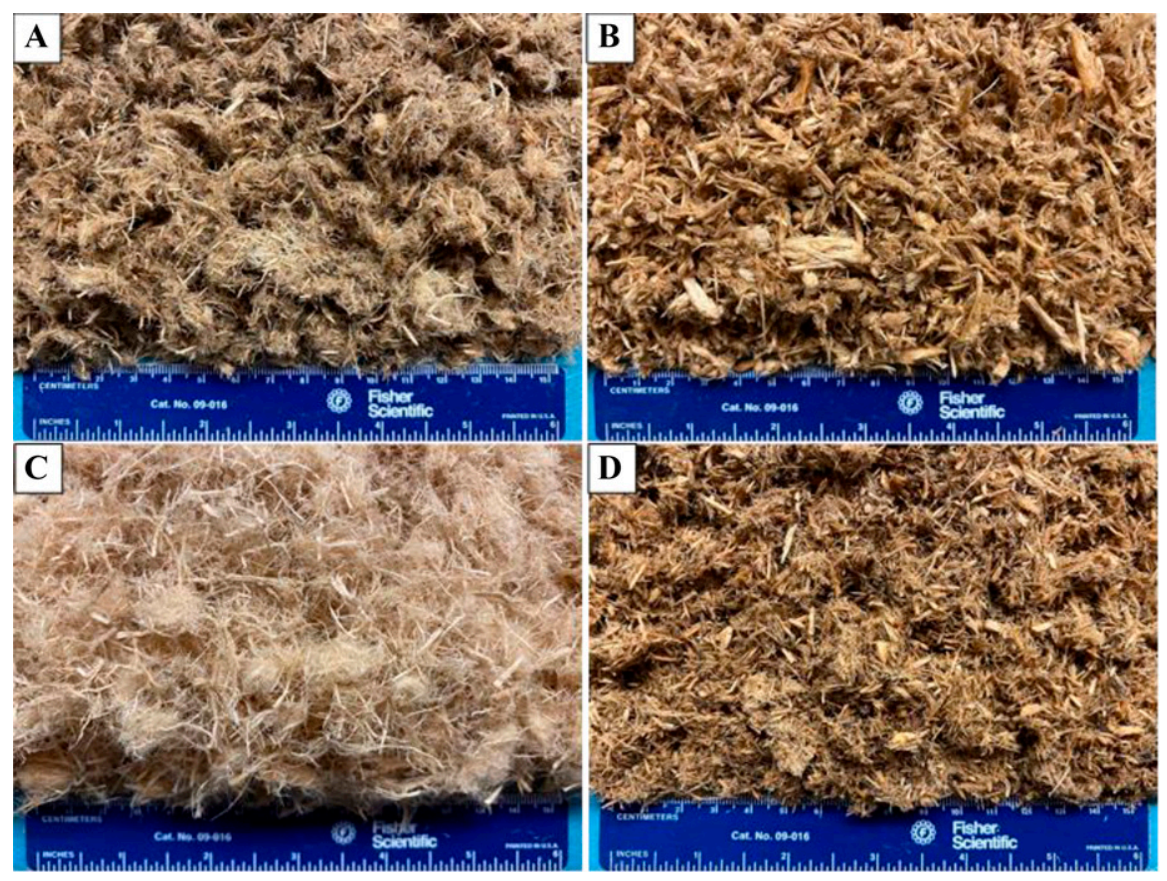

Fig. 1 Pictures of ForestGold (A), GreenFibre (B), HydraFiber (C), and pine tree substrate (D) components. 
Table 2. Total porosity, air porosity, water porosity, and dry bulk density measured on individual substrate components.

\begin{tabular}{lcccc}
\hline Component & $\begin{array}{c}\text { Total porosity } \\
(\% \text { by volume })\end{array}$ & $\begin{array}{c}\text { Air porosity } \\
(\% \text { by volume })\end{array}$ & $\begin{array}{c}\text { Container capacity } \\
(\% \text { by volume })\end{array}$ & $\begin{array}{c}\text { Dry bulk } \\
\text { density }\left(\mathrm{g} \cdot \mathrm{L}^{-1}\right)\end{array}$ \\
\hline Peat & $74.8 \mathrm{c}$ & $21.7 \mathrm{~d}$ & $53.1 \mathrm{bc}$ & $100.3 \mathrm{bc}$ \\
Perlite & $74.3 \mathrm{c}$ & $54.8 \mathrm{a}$ & $19.5 \mathrm{~d}$ & $130.0 \mathrm{~b}$ \\
Coir & $90.9 \mathrm{ab}$ & $12.5 \mathrm{e}$ & $78.3 \mathrm{a}$ & $70.0 \mathrm{c}$ \\
Bark & $78.7 \mathrm{c}$ & $28.5 \mathrm{~cd}$ & $50.2 \mathrm{c}$ & $276.7 \mathrm{a}$ \\
FG & $96.2 \mathrm{a}$ & $35.5 \mathrm{~b}$ & $60.8 \mathrm{~b}$ & $50.0 \mathrm{c}$ \\
GF & $90.7 \mathrm{ab}$ & $30.3 \mathrm{bc}$ & $60.4 \mathrm{~b}$ & $153.3 \mathrm{~b}$ \\
HF & $94.7 \mathrm{a}$ & $33.8 \mathrm{~b}$ & $61.0 \mathrm{~b}$ & $60.0 \mathrm{c}$ \\
PTS & $85.9 \mathrm{~b}$ & $25.1 \mathrm{~cd}$ & $60.8 \mathrm{~b}$ & $143.3 \mathrm{~b}$ \\
& $* * *$ & $* * *$ & $* *$ & $* * *$ \\
\hline
\end{tabular}

Data represent least-square means of three replicates. Means separation used Tukey's honestly significant difference at $\alpha=0.05$. Physical properties were measured using the North Carolina State University Porometer Method (Fonteno et al., 1995). FG = ForestGold; GF = GreenFibre; HF = HydraFiber; PTS $=$ pine tree substrate.

***Significant at $P \leq 0.0001$.

A

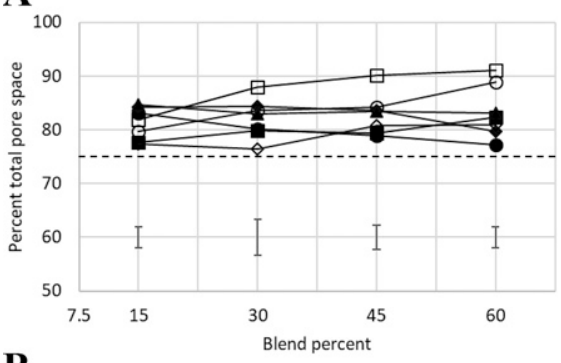

B

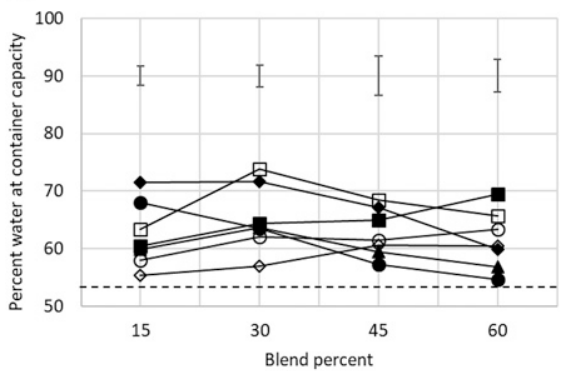

C
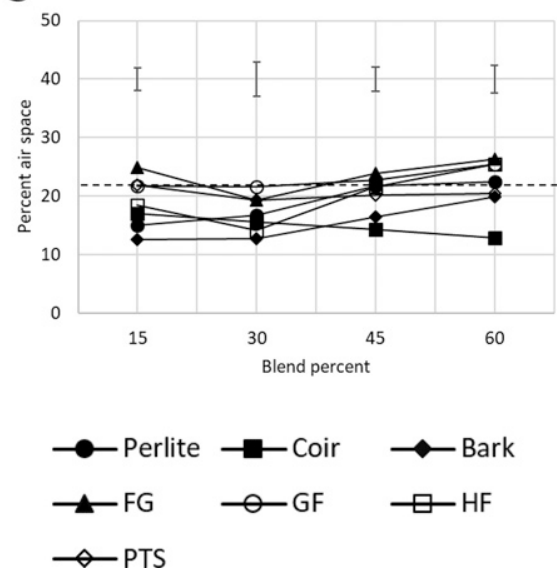

Fig. 2. Blend component and blend percent effects on percent total porosity $(\mathbf{A})$, percent water space at container capacity (B), and percent air space $(\mathbf{C})$ of substrate samples not used for growing plants. Data represent least-square means of three replicates per treatment, and error bars represent the $95 \%$ confidence interval around each mean. The horizontal dashed line indicates value for $100 \%$ peat for comparison, also shown in Table 2. $\mathrm{FG}=$ ForestGold, GF $=$ GreenFibre, $\mathrm{HF}=$ HydraFiber, PTS $=$ pine tree substrate. production, particularly substrates with high wood percentages (Fields et al., 2014), which was observed for peat blended with $\mathrm{HF}$ and GF in this study (Fig. 2A).

Air space and $\mathrm{CC}$ were also affected by the interaction of blend component and blend percent (Fig. 1B and C). Air space and $\mathrm{CC}$ increased as the blend percent increased with GF, HF, and PTS (Fig. 2), whereas only AS increased with coir (Fig. 2B). In contrast, CC decreased as the blend percent increased with bark and perlite (Fig. 2B). The FG in this study had similar texture and particle size distribution to the coarse sphagnum peat (Table 1) and had minimal effects on $\mathrm{TP}$ as blend percent increased (Fig. 2).

Substrate dry bulk density increased as the blend percent increased with perlite, bark, GF, and PTS (Fig. 3), likely because these components had a greater bulk density compared with peat, as shown in Table 2. In contrast, FG and HF and coir had lower dry bulk densities compared with peat and therefore reduced dry bulk density in the blended substrates as
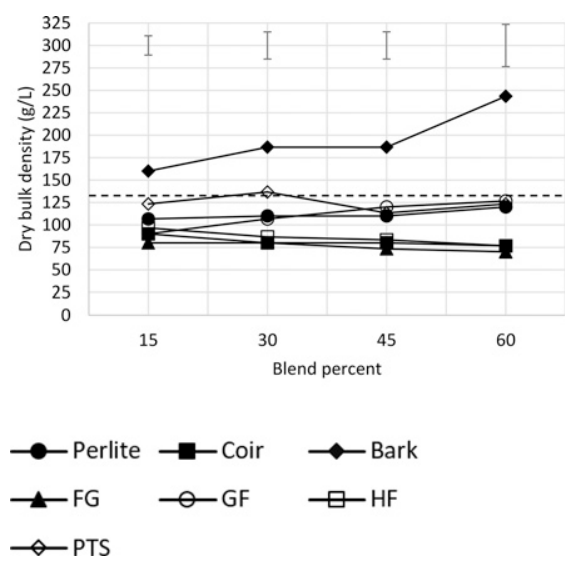

Fig. 3. Blend component and blend percent effects on substrate dry bulk density for samples not used for growing plants. Data represent least-square means of three replicates per treatment, and error bars represent the 95\% confidence interval around each mean. The horizontal dashed line indicates the value for $100 \%$ peat for comparison, also shown in Table 2. FG = ForestGold, GF = GreenFibre, $\mathrm{HF}=$ HydraFiber, PTS $=$ pine tree substrate. blend percent increased (Fig. 3). The dry bulk density for aged bark was greater compared with the other components (Table 2), resulting in a substantially higher substrate dry bulk density when blended with peat.

$N$ immobilization of individual substrate components. Substrate components differed in extracted $\mathrm{N}$, and the potential for $\mathrm{N}$ immobilization was measured as the difference in extracted $\mathrm{N}$ between 0 and $21 \mathrm{~d}$ of incubation (Table 3). Similar proportions of $\mathrm{NH}_{4}-\mathrm{N}$ and $\mathrm{NO}_{3}-\mathrm{N}$ were extracted from all samples, and therefore only total $\mathrm{N}$ (combined $\mathrm{NH}_{4}-\mathrm{N}$ and $\mathrm{NO}_{3}-\mathrm{N}$ ) data are reported. Extracted $\mathrm{N}$ was less than the initial $\mathrm{N}$ application (1000 $\mathrm{mg} \mathrm{N}$ per liter of substrate) at $0 \mathrm{~d}$, and the difference likely represents a fraction of $\mathrm{N}$ that was not immobilized but remained embedded within the substrate matrix. The difference in extracted $\mathrm{N}$ by $21 \mathrm{~d}$ was $\pm 50 \mathrm{mg} \mathrm{N}$ ( $\pm 5 \%$ of total $\mathrm{N}$ applied) for most components (Table 3), indicating minimal potential for immobilization/mineralization according to this test method (VDLUFA, 2007). The exception was for bark, where the difference in extracted $\mathrm{N}$ for bark was $-70.3 \mathrm{mg} \mathrm{N}(-9 \%$ reduction in extracted $\mathrm{N})$ and indicated a slightly greater potential for immobilization. Overall, the wood components in this study showed a low potential to immobilize fertilizer $\mathrm{N}$ according to guidelines for the VDLUFA (2007) method.

Plant growth experiment. At the end of the experiment, all petunia for each blended substrate treatment had dark green foliage, high flower counts, and appeared to be of a high market quality. Blended component had main effects on substrate EC, leaf SPAD chlorophyll content, shoot dry weight, flower number, and canopy height and width (Table 4). Blend percent had main effects on substrate EC, shoot dry weight, and flower number (Table 4). There were no interaction effects between blend component and blend percent for variables reported in Table 4 .

Blend component and blend percent interacted in effect on final substrate $\mathrm{pH}$ (Fig. 4). Substrate $\mathrm{pH}$ dropped to $\mathrm{pH} 5.0$ with bark blended at $60 \%$, whereas $\mathrm{pH}$ was unaffected by blend percent for the remaining components (Fig. 4). With the exception of bark blended at $60 \%$, final substrate $\mathrm{pH}$ and EC values remained within acceptable ranges for containerized bedding plants fertilized at each irrigation event ( $\mathrm{pH}$ from 5.4 and 6.4, EC from 1.0 to $2.5 \mathrm{mS} \cdot \mathrm{cm}^{-1}$; Nelson, 2011).

Final shoot dry weight was greatest for petunia grown in $100 \%$ peat and lower with the blended substrates and tended to decrease as the blend percent increased (Table 4). For the blended substrates, shoot dry weight was highest with bark and lowest with GF (Table 4), and these materials also resulted in the lowest and highest substrate $\mathrm{pH}$, respectively. Petunia tends to be susceptible to micronutrient deficiency at high pH (Argo and Fisher, 2002), and although there were no visual symptoms of micronutrient deficiency, it is possible the higher $\mathrm{pH}$ with GF caused a slight reduction in shoot growth compared with the lower $\mathrm{pH}$ blended bark substrates (average $\mathrm{pH}$ 5.4). 
Table 3. Substrate component effects on extracted nitrogen $(\mathrm{N})$ and percent reduction in $\mathrm{N}$ after $21 \mathrm{~d}$. The difference in extracted $\mathrm{N}$ per $\mathrm{L}$ of sample was measured between 0 and $21 \mathrm{~d}$. N extraction followed guidelines from the Association of German Agricultural Analytic and Research Institute's procedure for testing $\mathrm{N}$ immobilization/mineralization in soilless substrates (VDLUFA, 2007).

\begin{tabular}{|c|c|c|c|c|}
\hline Component & $\mathrm{N}$ extracted at $0 \mathrm{~d}\left(\mathrm{mg} \cdot \mathrm{L}^{-1}\right)$ & $\mathrm{N}$ extracted at $21 \mathrm{~d}\left(\mathrm{mg} \cdot \mathrm{L}^{-1}\right)$ & Difference in extracted $\mathrm{N}\left(\mathrm{mg} \cdot \mathrm{L}^{-1}\right)$ & $\%$ reduction in $\mathrm{N}$ \\
\hline Peat & $784.7 \mathrm{~d}$ & $754.0 \mathrm{bc}$ & $-30.3 \mathrm{abc}$ & $-4.0 \% \mathrm{ab}$ \\
\hline Coir & $886.0 \mathrm{a}$ & $887.0 \mathrm{a}$ & $1.0 \mathrm{ab}$ & $0.0 \% \mathrm{a}$ \\
\hline Bark & $788.7 \mathrm{~d}$ & $721.3 \mathrm{c}$ & $-70.3 \mathrm{c}$ & $-9.0 \% \mathrm{~b}$ \\
\hline FG & $877.7 \mathrm{ab}$ & $900.7 \mathrm{a}$ & $22.7 \mathrm{a}$ & $2.7 \% \mathrm{a}$ \\
\hline GF & $848.3 \mathrm{abc}$ & $811.3 \mathrm{~b}$ & $-37.3 \mathrm{bc}$ & $-4.3 \% \mathrm{ab}$ \\
\hline $\mathrm{HF}$ & 826.0 bcd & $810.7 \mathrm{~b}$ & $-15.0 \mathrm{abc}$ & $-2.0 \% \mathrm{ab}$ \\
\hline PTS & $\begin{array}{c}839.7 \text { abc } \\
* *\end{array}$ & $\begin{array}{c}806.7 \mathrm{~b} \\
* * *\end{array}$ & $-32.7 \mathrm{abc}$ & $\begin{array}{c}-3.7 \% \mathrm{ab} \\
* *\end{array}$ \\
\hline
\end{tabular}

Data represent least-square means of three replicates, and means separation used Tukey's honestly significant difference at $\alpha=0.05$. FG $=$ ForestGold; $\mathrm{GF}=$ GreenFibre; $\mathrm{HF}=$ HydraFiber; PTS $=$ pine tree substrate.

** Significant at $P \leq 0.01$.

Leaf SPAD chlorophyll content was relatively high across substrate treatments at values of $>35$ (Table 4), indicating no differences in foliage greenness. Harris et al. (2020) also reported high leaf SPAD chlorophyll content and minimal substrate effects on foliage color for petunia grown in peat blended with $30 \%$ (by volume) coconut coir, FG, and GF wood components.

Consistent with trends observed for shoot dry weight, flower number per plant was greatest with $100 \%$ peat and lower for the blended substrates, particularly with GF, and decreased as the blend percent increased (Table 4). Flower number was positively correlated with shoot dry weight per replicate across substrate treatments $[r>0.90$ (data not shown)], indicating plants with greater shoot growth also had a greater number of flowers. In general, flower number remained high across substrate treatments at $>100$ flowers per plant, which would be considered adequate for petunia grown commercially in hanging-basket containers.

Plant canopy width was greatest for petunia grown in $100 \%$ peat and was lower with the blended substrates (Table 4), particularly with pine wood fiber (FG, GF, HF) and perlite blends. Harris et al. (2020) also found reduced canopy width and a more compact growth habit with the same petunia variety grown in two sources of sphagnum peat blended with FG and GF pine fibers. The maximum difference in canopy height was only $4 \mathrm{~cm}$ between peat blended with bark and with perlite (Table 4), and although statistically significant, the impacts on canopy height were considered minimal.

Blend component and blend percent interacted in effect on maximum substrate $\mathrm{CC}$ (Fig. 5A). Increasing the blend percent decreased $\mathrm{CC}$ with perlite and $\mathrm{HF}$, increased $\mathrm{CC}$ with coir, and had no effects on the remaining components (Fig. 5A). Overall, $\mathrm{CC}$ was lowest with perlite at $60 \%(1.7 \mathrm{~L}$ per container) and greatest with coir at $45 \%$ (2.7 $\mathrm{L}$ per container) (Fig. 5A). Total $\mathrm{CC}$ for $100 \%$ peat was $2.3 \mathrm{~L}$ per container (Fig. $5 \mathrm{~A}$ ).

The volume of applied fertilizer solution per container during the experiment was also influenced by the interaction between blend component and blend percent (Fig. 5B). Increasing the blend percent decreased the applied fertilizer volume for with perlite, bark, FG, HF, and PTS (Fig. 5B) and had no effect on peat blended with coir and GF. Overall, total applied fertilizer solution was lowest with FG at $60 \%$ (9.0 L per container) and greatest with coir at $15 \%(14.7 \mathrm{~L}$ per container) (Fig. 5B). Total applied solution for $100 \%$ peat was $13.6 \mathrm{~L}$ per container (Fig. $5 \mathrm{~B}$ ). Applied fertilizer solution in Fig. 3D-F was positively correlated with shoot dry weight values from Table $4[r=0.8$ (data not shown)], indicating that plants with greater shoot growth required more fertigation solution.

Blend component and blend percent interacted in effect on the number of fertigation events per container (Fig. 5C). However, increasing the blend percent for any given component resulted in an increase or decrease of only one fertigation event per container. Overall, the total number of fertigation events ranged from 10 with GF blended at $30 \%$ to 13 with coir at $45 \%$ (Fig. $5 \mathrm{I}$ ), for a maximum difference of only three fertigation events across treatments during the $56 \mathrm{~d}$ growing period. There were 11 fertigation events for the $100 \%$ peat substrate (Fig. $5 \mathrm{C}$ ).

Table 4. Main effects for blended component and blend percent on substrate electrical conductivity (EC), shoot dry weight, leaf SPAD chlorophyll content, flower number, canopy height, and canopy width per plant at $56 \mathrm{~d}$ for container-grown petunia.

\begin{tabular}{|c|c|c|c|c|c|c|}
\hline & $\begin{array}{l}\text { Substrate EC } \\
\left(\mathrm{mS} \cdot \mathrm{cm}^{-1}\right)\end{array}$ & $\begin{array}{c}\text { Shoot dry } \\
\text { wt (g) }\end{array}$ & $\begin{array}{l}\text { Leaf SPAD } \\
\text { chlorophyll }\end{array}$ & $\begin{array}{c}\text { Flower no. } \\
\text { per plant }\end{array}$ & $\begin{array}{l}\text { Canopy } \\
\text { ht }(\mathrm{cm})\end{array}$ & $\begin{array}{c}\text { Canopy } \\
\text { width }(\mathrm{cm})\end{array}$ \\
\hline Peat (100\% peat control) & 1.83 & 35.9 & 39.9 & 189 & 16.3 & 70.7 \\
\hline $\pm 95 \%$ confidence limit & \pm 0.13 & \pm 2.0 & \pm 1.7 & \pm 14 & \pm 1.9 & \pm 4.7 \\
\hline \multicolumn{7}{|l|}{ Blend component } \\
\hline Perlite & $1.91 \mathrm{abc}$ & $31.6 \mathrm{abc}$ & $43.4 \mathrm{a}$ & $168 \mathrm{a}$ & $15.3 \mathrm{c}$ & $59.9 \mathrm{ab}$ \\
\hline Coir & $2.03 \mathrm{ab}$ & $33.6 \mathrm{ab}$ & $40.5 \mathrm{~b}$ & $169 \mathrm{a}$ & $16.7 \mathrm{bc}$ & $65.2 \mathrm{ab}$ \\
\hline Bark & $2.14 \mathrm{a}$ & $34.5 \mathrm{a}$ & $41.2 \mathrm{ab}$ & $163 \mathrm{ab}$ & $19.3 \mathrm{a}$ & $66.7 \mathrm{a}$ \\
\hline FG & $1.78 \mathrm{bc}$ & $27.7 \mathrm{~cd}$ & $40.2 \mathrm{~b}$ & $138 \mathrm{bc}$ & $17.5 \mathrm{ab}$ & $57.4 \mathrm{~b}$ \\
\hline GF & $1.66 \mathrm{c}$ & $26.4 \mathrm{~d}$ & $39.0 \mathrm{~b}$ & $123 \mathrm{c}$ & $16.8 \mathrm{bc}$ & $58.7 \mathrm{~b}$ \\
\hline $\mathrm{HF}$ & $1.86 \mathrm{bc}$ & $30.3 \mathrm{bcd}$ & $41.2 \mathrm{ab}$ & $152 \mathrm{ab}$ & $17.7 \mathrm{ab}$ & $59.8 \mathrm{ab}$ \\
\hline PTS & $1.78 \mathrm{bc}$ & $31.7 \mathrm{abc}$ & $40.3 \mathrm{~b}$ & $155 \mathrm{ab}$ & $16.7 \mathrm{bc}$ & $64.5 \mathrm{ab}$ \\
\hline $\pm 95 \%$ confidence limit & \pm 0.14 & \pm 2.3 & \pm 1.2 & \pm 13 & \pm 1.1 & \pm 4.2 \\
\hline Blend percent & $* * *$ & $* * *$ & $* * *$ & $* * *$ & $* * *$ & $* *$ \\
\hline $15 \%$ & $2.01 \mathrm{a}$ & $32.6 \mathrm{a}$ & $41.4 \mathrm{a}$ & $162 \mathrm{a}$ & $17.9 \mathrm{a}$ & $60.8 \mathrm{a}$ \\
\hline $30 \%$ & $1.91 \mathrm{ab}$ & $32.3 \mathrm{a}$ & $40.5 \mathrm{a}$ & $161 \mathrm{ab}$ & $16.9 \mathrm{a}$ & $63.0 \mathrm{a}$ \\
\hline $45 \%$ & $1.81 \mathrm{~b}$ & $31.4 \mathrm{a}$ & $41.0 \mathrm{a}$ & $154 \mathrm{ab}$ & $16.9 \mathrm{a}$ & $61.0 \mathrm{a}$ \\
\hline $60 \%$ & $1.77 \mathrm{~b}$ & $27.2 \mathrm{~b}$ & $41.4 \mathrm{a}$ & $138 \mathrm{~b}$ & $17.2 \mathrm{a}$ & 59.9 a \\
\hline \multirow[t]{2}{*}{ $\pm 95 \%$ confidence limit } & \pm 0.12 & \pm 1.9 & \pm 1.0 & \pm 11 & \pm 0.9 & \pm 3.5 \\
\hline & $* *$ & $* * *$ & NS & $* *$ & NS & NS \\
\hline
\end{tabular}

Data represent least-square means of 16 and 28 replicates for blend component and blend percent, respectively. Mean separation used Tukey's honestly significant difference with $\alpha=0.05$. Data also include the mean ( 8 replicates) for the $100 \%$ peat reference substrate and $95 \%$ confidence intervals. FG $=$ ForestGold; GF = GreenFibre; HF = HydraFiber; PTS = pine tree substrate. NS, **, ***Nonsignificant or significant at $P \leq 0.01$ or 0.0001 , respectively. 


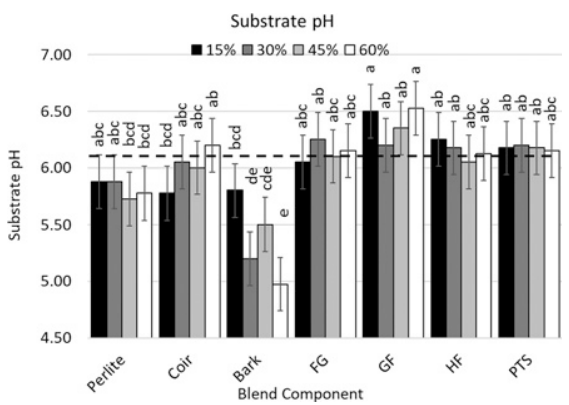

Fig. 4. Blend component and blend percent interaction effects on final substrate $\mathrm{pH}$ after production of petunia in hanging baskets. Data represent least-square means of 28 replicates. Error bars represent the $95 \%$ confidence interval around each mean. Means separation used Tukey's honestly significant difference at $\alpha=$ 0.05 . The horizontal dashed line indicates the value for $100 \%$ peat for comparison. $\mathrm{FG}=$ ForestGold, GF = GreenFibre, $\mathrm{HF}=$ HydraFiber, PTS = pine tree substrate.

Blend component and blend percent interacted in effects on percent shoot tissue $\mathrm{N}$ (Fig. 6A). Shoot tissue $\mathrm{N}$ was lowest with
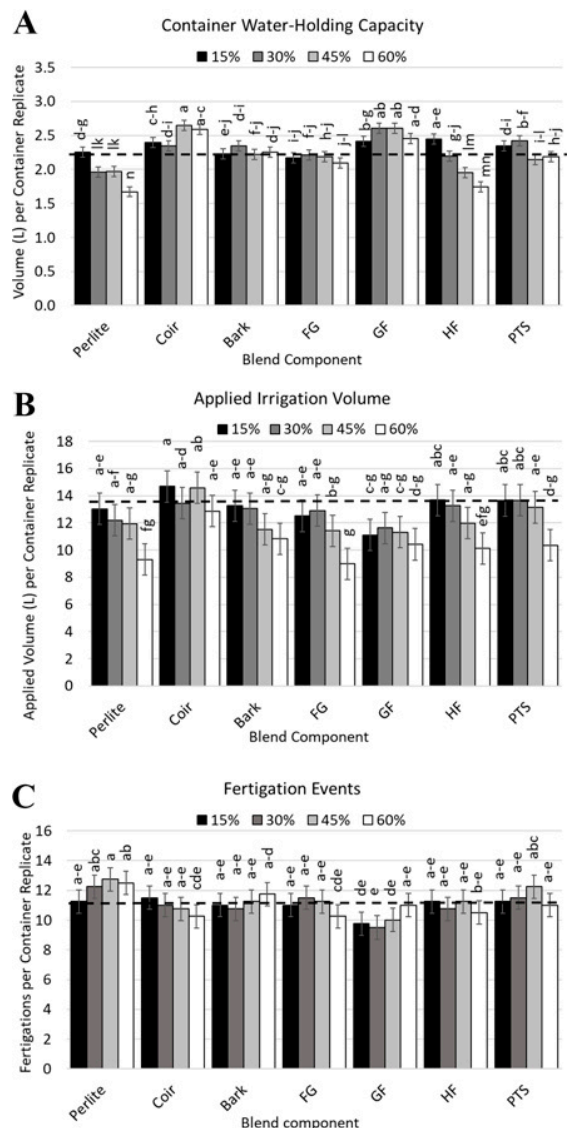

Fig. 5. Blend component and blend percent interaction effects on container water-holding capacity (A), total applied volume of fertigation solution (B), and the number of fertigation events (C) during production of petunia in hanging baskets. Data represent least-square means of 28 replicates. Error bars represent the $95 \%$ confidence interval around each mean. Means separation used Tukey's honestly significant difference at $\alpha=0.05$. Horizontal dashed lines indicate the value for $100 \%$ peat for comparison. $\mathrm{FG}=$ ForestGold, $\mathrm{GF}=$ GreenFibre, $\mathrm{HF}=$ HydraFiber, $\mathrm{PTS}=$ pine tree substrate . peat blended with GF and PTS and decreased as the blend percent increased for these components (Fig. 6A), whereas shoot tissue $\mathrm{N}$ increased with blend percent for peat blended with $\mathrm{HF}$ and was minimally affected by blend percent for the remaining components (Fig. $6 \mathrm{~A})$. Shoot tissue $\mathrm{N}$ ranged from $3.30 \% \mathrm{~N}$ with GF blended at $60 \%$ to $4.08 \% \mathrm{~N}$ with $\mathrm{HF}$ blended at $60 \%$ and was $3.85 \% \mathrm{~N}$ with the $100 \%$ peat (Fig. 6A). Overall, percent shoot tissue $\mathrm{N}$ was either near or below the lower limit of the recommended sufficiency range for petunia $(3.85 \% \mathrm{~N}$ to $7.60 \% \mathrm{~N}$; Bryson et al., 2014). Shoot tissue $N$ may have appeared low because the analyzed samples contained significant amounts of stem tissue, which typically have lower nutrient levels compared with leaves (Bugbee, 2004), and tissue nutritional standards are often based on leaf tissue analysis.

Blend component and blend percent influenced the accumulation of shoot tissue N (Fig. 6D-F). On average, the accumulation of shoot $\mathrm{N}$ was greatest with bark (1313.0 mg N/plant) and lowest with GF (963.1 mg N/plant), as shown in Fig. 6D, and accumulated shoot $\mathrm{N}$ tended to decrease as the blend percent increased (Fig. 4E and F). Compared with the blended substrate treatments, accumulated shoot $\mathrm{N}$ was still greater with $100 \%$ peat substrate at $1380.4 \mathrm{mg} \mathrm{N} /$ plant (Fig. 6D-F). These trends were similar to those observed for shoot dry weight in Table 4, and differences in shoot $\mathrm{N}$ accumulation resulted mainly from differences in total shoot growth.
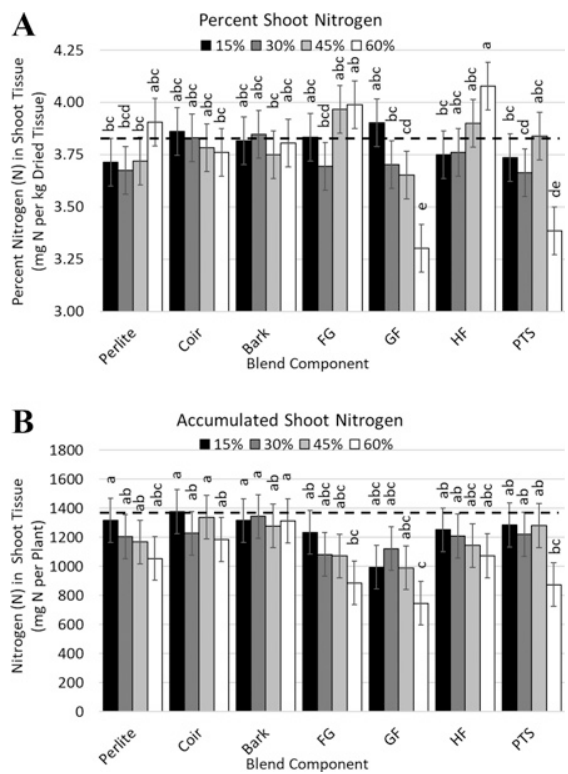

Fig. 6. Blend component and blend percent interaction effects on percent shoot nitrogen (A) and accumulated shoot tissue $\mathrm{N}$ (B) during production of petunia in hanging baskets. Data represent least square means of 28 replicates. Error bars represent the 95\% confidence interval around each mean. Means separation used Tukey's honestly significant difference at $\alpha=0.05$. Horizontal dashed lines indicate the value for $100 \%$ peat for comparison. $\mathrm{FG}=$ ForestGold, GF = GreenFibre, $\mathrm{HF}=$ HydraFiber, PTS = pine tree substrate.
Results indicate that peat-based substrates blended with any of the four alternative wood components are suitable for petunia production in hanging-basket containers, as evidenced by relatively high leaf SPAD chlorophyll index values $(\geq 39.0)$ and flower number per plant ( $\geq 123$ flowers/plant; see Table 4). Petunia grown in peat blended with wood, particularly FG, GF, and HF, had reduced shoot growth, canopy width, flower number, and shoot tissue $\mathrm{N}$ compared with plants grown in $100 \%$ peat. However, overall plant performance was comparable to petunia grown in peat blended with perlite, coir, and aged bark (Table 4). With constant fertigation in a commercial greenhouse operation, it would be straightforward to increase the applied fertilizer level if needed to compensate for $\mathrm{N}$ immobilization when producing petunia in wood fiber blends.

Substrate CC was greater for peat blended with pine wood components compared with perlite (Fig. 5A and C), although AS was similar (Fig. 2C). The pine wood fibers also had similar textures to peatmoss (Maher et al., 2008), especially FG and HF, which may have contributed to the relatively high water retention and air porosity. Similar to reports from Harris et al. (2020), results in this study found that blending peat and pine wood fiberscomponents with similar textures and particle size distributions - had minimal effects on substrate TP and CC compared with blending components differing in physical properties.

The laboratory methods used in this study indicated a low potential for $\mathrm{N}$ immobilization for wood components (Table 3), despite plant growth being the least in substrates containing wood fiber and PTS. According to data in Table 3, bark would have been expected to have the greatest $\mathrm{N}$ immobilization. However, peat blended with bark tended to result greater shoot dry weights and flowering compared with the other wood components. Harris et al. (2020) also reported decreased growth and flowering for petunia in peat amended with wood fiber (FG and GF) and PTS, which had a low potential for $\mathrm{N}$ immobilization, and suggested alternative testing methods may be needed. Blok et al. (2008) reported biological respiration measured as the consumption of oxygen $\left(\mathrm{O}_{2}\right)$ or production of carbon dioxide $\left(\mathrm{CO}_{2}\right)$ as a reliable method for determining the stability of organic soilless substrates. Bugbee and Heins (2018) showed biological oxygen demand was 2-fold greater for sawdust and shredded wood materials compared with sphagnum peat, and demand increased another 2-fold when materials were incubated with $\mathrm{N}$. Jackson et al. (2009) found similar trends measuring $\mathrm{CO}_{2}$ production with peat substrates blended with PTS, where $\mathrm{CO}_{2}$ efflux was greater as blend percent increased and was positively correlated with applied fertilizer N. Biological activity would also increase with easily degradable organic materials and during $\mathrm{N}$ mineralization ( $\mathrm{N}$ release) and would need to be accounted for when using $\mathrm{O}_{2}$ consumption $/ \mathrm{CO}_{2}$ efflux to evaluate $\mathrm{N}$ immobilization in wood fiber substrates. 
Shoot dry weight gain and accumulation of $\mathrm{N}$ in shoot tissue are useful methods to evaluate $\mathrm{N}$ availability in wood substrates and resulting effects on plant growth (Harris et al., 2020). Shoot dry weight and accumulation of shoot tissue $\mathrm{N}$ was greatest with $100 \%$ peat at the end of production, whereas shoot dry weight and $\mathrm{N}$ accumulation were lowest for wood fiber blends (Fig. 6), particularly with GF. Decreased shoot growth for petunia grown in wood fiber blends was also correlated with decreased flower number and plant canopy width (Table 4), which are other indicators of plant performance and quality. Analyzing dry shoot tissue for nutrient concentrations is a common method for monitoring crop fertility, and therefore many horticultural operations may already collect the measurements needed to calculate shoot dry weight and $\mathrm{N}$ accumulation. Comparing plant growth and $\mathrm{N}$ uptake between plants grown in peat blended with pine wood fiber vs. other components or $100 \%$ peat may be a practical approach for growers and substrate manufacturers to evaluate substrates in horticultural practice.

Previous research has consistently shown that increasing wood proportions tends to increase N immobilization (Handreck, 1993; Jackson et al., 2008; Prasad, 1996a; Wright et al., 2008), especially with greater than $40 \%$ wood by volume. Plant growth, flowering, and accumulated shoot tissue $\mathrm{N}$ decreased as the blend percent increased to $45 \%$ and $60 \%$ across components, including perlite, suggesting potential $\mathrm{N}$ immobilization was not the only growth limiting factor. Aged bark had the least effect on plant performance (shoot growth, flowering, leaf SPAD, shoot tissue N) after increasing the blend percent (data not shown), despite having the greatest potential for $\mathrm{N}$ immobilization in Table 3 . It is possible the decreased plant growth and flowering at the higher blend percentages was partially a result of decreased substrate water-holding capacity and nutrient level caused by a reduction in volumetric peat. However, this does not fully explain the main differences in growth between blended components. Past research has also shown certain wood materials to leach growth inhibiting compounds into the root zone (Bugbee and Heins, 2018; Bunt, 1988; Ortega et al., 1996), particularly if the wood was not adequately aged or processed. Similarly, certain peat and coir materials have been reported to release organic compounds that promote root and shoot growth (Maher et al., 2008).

Based on results from this study, blending peat with up to $30 \%$ pine wood components would likely require minimal adjustment to the fertilizer and irrigation programs during production of container-grown petunia. Increasing the proportion of pine wood to greater than $30 \%$ of the substrate volume may require commercial growers to increase $\mathrm{N}$ fertilization and adjust irrigation practices to maintain optimal plant growth.

\section{Conclusions}

This study illustrates the challenges of measuring $\mathrm{N}$ immobilization in horticultural substrates because results from the laboratory study were not consistent with plant performance in the greenhouse. In addition, it is difficult to parse apart the interacting effects in a horticulture study. Increasing blends of each substrate (including perlite) were observed to interact with irrigation volume and therefore applied N, tissue N, shoot dry weight, and total uptake. As a practical conclusion from this study, peat incorporated with $60 \%$ pine wood fiber increased the risk of reduced plant growth and $\mathrm{N}$ uptake, but this risk was lower as the blend percentage decreased. In addition, use of other analytical methods to test $\mathrm{N}$ immobilization, such as microbial respiration, should be further explored.

\section{Literature Cited}

Argo, W.R. 1998. Root medium physical properties. HortTechnology 8:481-485, https://doi. org/10.21273/HORTTECH.8.4.481.

Argo, W.R. and P.R. Fisher. 2002. Understanding $\mathrm{pH}$ management for container grown crops. Meister Publ., Willoughby, OH.

Barrett, G.E., P.D. Alexander, J.S. Robinson, and N.C. Bragg. 2016. Achieving environmentally sustainable growing media for soilless plant cultivation systems: A review. Scientia Hort. 212: 220-234, https://doi.org/10.1016/j.scienta.2016. 09.030 .

Bartley, P.C. III. 2019. Multidimensional characterization of horticultural substrates. Thesis, NC State University.

Blok, C., C. de Kreij, R. Baas, and G. Wever. 2008. Analytical methods used in soilless cultivation, p. 245-289. In: M. Raviv and J.H. Lieth (eds.). Soilless culture, theory and practice. Elsevier, London, UK

Bryson, G.M., H.A. Mills, D.N. Sasseville, J.B. Jones, and A.V. Barker. 2014. Plant analysis handbook III: A guide to sampling, preparation, analysis, interpretation and use of results of agronomic and horticultural crop plant tissue. Micro-Macro Publishing, Inc., Athens, GA.

Bugbee, B. 2004. Nutrient management in recirculating hydroponic culture. Acta Hort. 648: 99-112, https://doi.org/10.17660/ActaHortic. 2004.648.12.

Bugbee, B. and R. Heins. 2018. Wood products in the root zone. 11 Nov. 2019. <https://gpnmag. com/article/woodproducts-in-the-root-zone/ $>$.

Bunt, A.C. 1988. Media and mixes for containergrown plants. Unwin Hyman, London, UK.

Drotleff, L. 2018. HydraFiber soaks up horticulture market share with wood fiber media. 28 Dec. 2018. <https://www.greenhousegrower.com/ production/media/hydrafiber-soaks-up-horticulture market-share-with-wood-fiber-media/>.

Fields, J.S., W.C. Fonteno, B.E. Jackson, J.L. Heitman, and J.S. Owen. 2014. Hydrophysical properties, moisture retention, and drainage profiles of wood and traditional components for greenhouse substrates. HortScience 49:827-832, https://doi.org/10.21273/HORTSCI.49.6.827.

Fonteno, W.C., C.T. Hardin, and J.P. Brewster. 1995. Procedures for determining physical properties of horticultural substrates using the NCSU Porometer. Horticultural Substrates Laboratory, North Carolina State University.

Geisseler, D., W.R. Horwath, R.G. Joergensen, and B. Ludwig. 2010. Pathways of nitrogen utilization by soil microorganisms: A review. Soil Biol. Biochem. 42:2058-2067, https://doi. org/10.1016/j.soilbio.2010.08.021.
Gruda, N., S. von Tucher, and W.H. Schnitzler. 2000. N-immobilization by wood fiber substrates in the production of tomato transplants. J. Appl. Bot. Food Qual. 74:32-37.

Handreck, K.A. 1992a. Rapid assessment of the rate of nitrogen immobilisation in organic components of potting media: I. Method development. Commun. Soil Sci. Plant Anal. 23:201-215, https://doi.org/10.1080/001036292 09368583 .

Handreck, K.A. 1992b. Rapid assessment of the rate of nitrogen immobilisation in organic components of potting media: II. Nitrogen drawdown and plant growth. Commun. Soil Sci. Plant Anal. 23:217-230, https://doi.org/10.1080/001036292 09368584.

Handreck, K.A. 1993. Use of the nitrogen drawdown index to predict fertilizer nitrogen requirements in soilless potting media. Commun. Soil Sci. Plant Anal. 24:2137-2151, https://doi.org/ 10.1080/00103629309368943.

Harris, C.N., R.W. Dickson, P.R. Fisher, B.E. Jackson, and A.M. Poleatewich. 2020. Evaluating peat substrates amended with pine wood fiber for nitrogen immobilization and effects on plant performance with container-grown petunia. HortTechnology 30:107-116, https://doi. org/10.21273/HORTTECH04526-19.

Jackson, B.E., R.D. Wright, and M.C. Barnes. 2008. Pine tree substrate, nitrogen rate, particle size, and peat amendment affect poinsettia growth and substrate physical properties. HortScience 43:2155-2161, https://doi.org/10.21273/ HORTSCI.43.7.2155.

Jackson, B.E., R.D. Wright, and M.M. Alley. 2009. Comparison of fertilizer nitrogen availability, nitrogen immobilization, substrate carbon dioxide efflux, and nutrient leaching in peat-lite, pine bark, and pine tree substrates. HortScience 44:781-790, https://doi.org/10.21273/HORTSCI. 44.3.781.

Maher, M., M. Prasad, and M. Raviv. 2008. Organic soilless media components, p. 459-504. In: M. Raviv and J.H. Lieth (eds.). Soilless culture, theory and practice. Elsevier, London, UK.

Nelson, P.V. 2011. Greenhouse operation and management. 7th ed. Prentice Hall, Upper Saddle River, NJ.

Ortega, M.C., M.T. Moreno, J. Ordovas, and M.T. Aguado. 1996. Behavior of different horticultural species in phytotoxicity bioassays of bark substrates. Scientia Hort. 66:125-132, https:// doi.org/10.1016/0304-4238(96)00900-4.

Prasad, M. 1996a. Physical, chemical and biological properties of coir dust. Acta Hort 450:21-29, https://doi.org/10.17660/ActaHortic, 1997.450.1.

Prasad, M. 1996b. Nitrogen fixation of various material from a number of European countries by three nitrogen fixation tests. Acta Hort. 450: 353-362, https://doi.org/10.17660/ActaHortic, 1997.450.143.

Purcell, L.C. and C.A. King. 1996. Total nitrogen determination in plant material by persulfate digestion. Agron. J. 88:111-113, https://doi. org/10.2134/agronj1996.0002196200880001 $0023 x$.

Puustjarvi, V. and R.A. Robertson. 1975. Physical and chemical properties, p. 23-38. In: D.W. Robinson and J.G.D. Lamb (eds.). Peat in horticulture. Academic Press, London, UK.

Raviv, M. 2005. Production of high-quality composts for horticultural purposes: A mini-review. HortTechnology 15:52-57, https://doi.org/ 10.21273/HORTTECH.15.1.0052.

Schulten, H.R. and M. Schnitzer. 1998. The chemistry of soil organic nitrogen: A review. Biol. 
Fertil. Soils 26:1-15, https://doi.org/10.1007/ s003740050335.

Sonneveld, C. and W. Voogt. 2009. Plant nutrition in future greenhouse production. Springer, Dordrecht, The Netherlands.

Association of German Agricultural Analytic and Research Institutes (VDLUFA). 2007. Methodenbuch I-Die Untersuchung von Böden: Methode
A 13.5.1 Stabilität N-Haushalt. 7. Teillieferung. Assn. German Agr. Analytic Research Inst., Speyer, Germany.

Wright, R.D. 1986. The pour through nutrient extraction procedure. HortScience 21:227-229.

Wright, R.D., B.E. Jackson, J.F. Browder, and J.G. Latimer. 2008. Growth of chrysanthemum in a pine tree substrate requires additional fertilizer.
HortTechnology 18:111-115, https://doi.org/ 10.21273/HORTTECH.18.1.111.

Yeager, T.H., D.C. Fare, J. Lea-Cox, J. Ruter, T.E. Bilderback, C.H. Gilliam, A.X. Niemiera, S.L. Warren, T.E. Whitwell, R.D. Wright, and K.M. Tilt. 2007. Best management practices: Guide for producing container-grown plants. 2nd ed. Southern Nurserymen's Assoc, Marietta, GA. 